\title{
UDC 615.224
}

DOI: 10.15587/2519-4852.2018.129813

\section{THE ANALYSIS OF THE SALE OF ANTIHYPERTENSIVE DRUGS IN THE PHARMACIES OF KYIV}

\author{
(C) I. Sakhanda, K. Kosyachenko, T. Nehoda
}

\begin{abstract}
Мета. Антигіпертензивні препарати (АГП) належать до категорії найбільш вжсваних лікарських засобів на фармацевтичному ринку Украйни. Це пов'язано із значною поширеністю артеріальної гіпертензії (АГ) у багатьох країнах світу, включаючи Украйну. Метою даного дослідження є розробка нового підходу до оптимізації фармакотерапії сериево-судинних захворювань у рамках фармацевтичної опіки на основі комплексної клінічної та економічної оцінок використання антигіпертензивних препаратів різних клінічних та фармакологічних груп, щзо проводиться з позицій аптечних закладів і амбулаторних
\end{abstract} лікарень та з урахуванням економічних інтересів пацієнтів.

Матеріали та методи. Дослідження було проведено ретроспективно в 100 приватних аптеках м. Києва (щоденні відвідувачі - 400-500 осіб). Аналіз асортименту АГП, який був досліджений в 2017 роиі, здійснювався за допомогою відповідної документації аптек. Для оцінки діапазону АГП на вітчизняному фармацевтичному ринку були використані дані інформаџійної системи "Медикаменти" компанії Morion (станом на жовтень 2017 р.).

Результати. Протягом даного часу антигіпертензивні препарати були представлені в аптеках у досить широкому асортименті, переважно іноземнихвиробників - 175 торговельних назв (TH), 43 міжнародні непатентованіназви (МНH). Загалом, майже половина МНH (56,58 \%) та 1/4 частини ТН (28,78\%) були представлені в аптеках загальної кількості АГП на фармацевтичному ринку України. Відповідно до результатів частотного аналізу, той самий АГП мав високий попитдля населення в аптеках протягом року, але иі препарати відрізнялися за рейтингом. Вони складають 21,41 \% всіх реалізованих упаковок АГП в аптеках - 19,67 \%. Лише два лікарських засоби серед лідерів-препаратів були іноземного виробництва, інші - вітчизняного. Вони мали відносно низьку вартість упаковки - до 10,00 грн. Отже, ціновий фактор часто вирішальний у виборі відвідувачів АГП в аптеках. Препаратами першої та другої ліній терапї̈, а також комбінованими АГП є ті засоби, які часто купували пацієнти в аптеках. Всі препарати першої лінії є представниками інгібіторів АПФ (еналаприл і каптоприл). Крім того, комбінований АГП Каптопрес-Д також містить інгібітор АПФ - каптоприл. Препарати иієї групи добре зарекомендували себе в клінічній практиці, вони можуть застосовуватися на будь-якій стадії гіпертонії та, безпосередньо, поліпшують якість життя хворих та прогноз захворювання, а також поєднання "інгібітор АПФ + тіазидовий діуретик" визнається одним з найбільш ефективних і доцільних для призначення комбінованої антигіпертензивної терапії. Тому лікарі часто призначають ичю фармакологічну групу пацієнтам з АГ. Проте високий попит на них серед відвідувачів аптек, ймовірно, пов'язаний саме з їх низькою вартістю.

Висновок. Отже, для того, щуоб забезпечити рачіональну фармакотерапію для лікування артеріальної гіпертензї, $і$ з огляду на те, щчо лише частина торгівельних найменувань антигіпертензивних препаратів, представлених на фармацевтичному ринку Украйни доступна в аптеках, доцільно оптимізувати діапазон АГП за результатами АBC-, VEN- та частотного аналізу

Ключові слова: антигіпертензивні препарати, АВC-, VEN-аналіз, артеріальна гіпертензія, серцевосудинні захворювання, комбінація

\section{Introduction}

Antihypertensive drugs (AHD) belong to the category of the most commonly used drugs in the pharmaceutical market of Ukraine. This is due to the significant prevalence of arterial hypertension $(\mathrm{AH})$ in many countries of the world, including Ukraine. According to official statistics, over 12 million patients with high blood pressure are registered in Ukraine [1], such patients make about $36 \%$ of the population in European countries and the USA [2]. Patients with hypertension often have to take AHD, so the result of treatment depends not only on the possibilities of modern diagnostics, professionalism of doctors, but also on the availability of the necessary assortment of AHD, their cost, financial ability of the payers.
2. Formulation of the problem in a general way, the relevance of the theme and its connection with important scientific and practical issues

The analysis of the economic feasibility of the use of antihypertensive drugs from various clinical and pharmacological groups, in particular on the basis of LRS, is very relevant, taking into account the breadth of their prevalence in the conditions of real clinical practice, as well as their therapeutic effectiveness, safety and influence on the well-being of patients. As a result of this analysis, recommendations will be directed not only on saving material resources, but also on increasing the effectiveness of pharmacotherapy of cardiovascular diseases. Ultimately, this will lead to significant cost savings not only for a particular patient, but for health and society as a whole. 
3. Allocation of unsolved parts of the general problem, which is dedicated to the article

At the same time, in the domestic information space, there are no papers in which the results of the analysis of sales of antihypertensive drugs in appeals of the Kyiv will be presented taking into account the growth of prices for medicines and also taking into account the dynamics of changes in the incidence of cardiovascular diseases in Ukraine in 2017.

\section{Statement of the basic material of the study (methods and objects) with the justification of the results}

The research was taken retrospectively in 100 commercial pharmacies in the city of Kyiv (daily visitors - 400-500).Analysis of the AHD assortment, which was presented in it in 2017, was carried out with the help of appropriate documentation of pharmacies. To assess the range of AHD on the domestic pharmaceutical market, the data of the "Medicines" information system of Morion Company were used (as of October 2017) [3].

According to the recommendations of the Ukrainian Association of Cardiology for the prevention and treatment of hypertension [4], to reduce the level of blood pressure and mortality from cardiovascular diseases, you should to use the AHD of the following groups:

1 . The first line of therapy is diuretics, $\beta$ adrenoblockers, angiotensin-converting enzyme (ACE) inhibitors, long-acting calcium antagonists, angiotensin II receptor antagonists.

2. The second line of therapy $\operatorname{are} \alpha_{1}$ adrenoblockers, central $\alpha_{2}$-agonists (clonidine, guanfacin, methyldopa), imidazoline receptor agonists (moxonidine).

3. The third line is the alkaloids of Rawolfia and other herbal medicines.

In a large number of cases, it is recommended to carry out combined antihypertensive therapy with monotherapy combinations or through the appointment of a fixed combination of antihypertensive drugs [5].

During the year there were available drugs of all the above-mentioned groups, including combined AHDs in pharmacies and in the pharmaceutical market of Ukraine. It should be noted the presence of representatives of new drugs for the treatment of hypertension [6] inhibitors of renin - aliskiren.

During the year, antihypertensive drugs were presented in pharmacies in a fairly wide assortment, mainly foreign products - 175 trade names (TN), 43 international non-proprietary names (INNs).In general, almost half of INNs $(56.58 \%)$ and $1 / 4$ part of TN $(28.78 \%)$ were presented in pharmacies of the total amount of AHD in the pharmaceutical market of Ukraine. Most AHD in pharmacies are mono-preparations of the first and second lines of therapy $\mathrm{AH}$ and combined antihypertensive drugs, in which they are included. This coincides with the situation on the pharmaceutical market of Ukraine in the investigated period and indicates the possibility of choosing AHD in accordance with modern approaches to treatment of hypertension [7]. The number of preparations of the third line of therapy is sufficiently limited both in the pharmacy $-7.4 \%$, and in Ukraine as a whole $-6.9 \%$. This can be explained by the fact that doctors considerably less have been prescribed this drugs to their patients in recent years due to the lack of sufficient evidence of an effective reduction of the risk of cardiovascular diseases compared with preparations of the first and second lines of therapy of hypertension [8].

The assessment of AHD consumption was carried out retrospectively in pharmacies during the year by comparing the results of $\mathrm{ABC}, \mathrm{VEN}$ and frequency analysis (integrated analysis) of their sale in 2016.

In the conditions of pharmacies, it is most convenient to carry out the formal VEN-analysis: the definition of the presence of a medicinal product in regulatory documents that regulate the provision of medicines. Under this approach, the drugs are divided into two groups: $\mathrm{V}$ (if they are available in the chosen regulatory document) and $\mathrm{N}$ (in their absence). In the pharmacies under investigation, the formal VEN-analysis was carried out for AHD, which was available in the range of pharmacies in 2016, with the help of the State Formula of Ukraine (second edition for 2010) $[9,10]$. According to the results of the frequency analysis, the same AHD was in high demand by the population in pharmacies during the year but thse drugs were differed in rating. These preparations make $21.41 \%$ of all sold packages of AHD in pharmacies $-19.67 \%$. Among them, the absolute leader in the number of packages sold for two years was the ACE inhibitor Enalapril (Table $5.0 \mathrm{mg}$ No. 20, Ozon LLC), which had one of the lowest prices for packaging among all AHDs in the pharmacy range - $3.56 \mathrm{UAH}$.

Only two drugs among the drug-leaders were foreign-made, others were domestic drugs. They had a relatively low packing cost - up to $10.00 \mathrm{UAH}$. Consequently, the price factor was often decisive in choosing AHD visitors to pharmacies.

Preparations of the first and second line of therapy, as well as combined AHD, are the drugs which were often bought by patients in pharmacies. Interestingly, all preparations of the first line of hypertension are representatives of ACE inhibitors (3 TN Enalapril and $1 \mathrm{TN}$ of Captopril). In addition, the combined AHD Captopress-D also contains an ACE inhibitor Captopril. Preparations of this group have been proved well in clinical practice, they can be used at any stage of hypertension, they improve the quality of life of patients and the prognosis of the disease [11], and the combination "ACE inhibitor + Thiazide diuretic" (among the leading drugs - the drug Captopress-D) is recognized as one of the most effective and appropriate for the appointment of combined antihypertensive therapy [12]. Therefore, doctors often prescribe this pharmacological group to patients with $\mathrm{AH}$. However, the high demand for them among drugstore visitors is likely related to their low cost.

Among other first-line anti-hypertension drugs, long-acting calcium antagonists and diuretics were also commonly used. The drugs of $\beta$-blockers and angiotensin II receptor antagonists occupy most of the average and last places in the frequency ranking. Most of the combined AHDs, which include first-line treatment of hypertension, had a moderate demand among the population.

A high rate of sales has also been recorded for second-line drugs, which have been used in the treatment of hypertension long. And these drugs are currently not a priority in the treatment of the disease. However, a large 
number of packages of the central $\alpha_{2}$ agonist of Clonulfine and Raunatin rauwolf alkaloids are indicative of the fact that they remain popular among the population. High demand is for two TN clonidine (KlofelinDarnitsa and Klofelin-Health) with the same dose, but different number of tablets in the packages particularly attracted attention. Over the study period, they account for $4.78 \%$ of all packaged AHD packaged in the pharmacy during these periods.

What was the place taken by the drug-leaders by the frequency of sold packages in the structure of pharmacy revenues from the sale of AHD. According to the results of the $\mathrm{ABC}$-analysis, most of the drug-leading leaders by the frequency of the sales were in group A (besides the drug Klofelin-Health) in 2017. The frequency of sales of top-of-the-line drugs (TOP-5), which gave the greatest revenues to pharmacies (Group A), was ranged from $0.25 \%$ to $0.91 \%$.Most of them are the same drugs in the first line of therapy: $\beta$-adrenoblockers - Talliton (Table $25 \mathrm{mg}$ No. 28) and Nebilet (Table $5 \mathrm{mg}$ No. 28); ACE inhibitor PRESTARIUM (Table $8 \mathrm{mg}$ No. 30). The new AHD - Renin Inhibitor, Rasilez (Table 300 mg No. 28), was the leader in sales of money among the leading drug manufacturers throughout the year. All preparations with TOP-5 are medicines of foreign manufacture, with the average and high cost of packing (from 92.25 to $350.00 \mathrm{UAH}$ ). And the very cost of packaging provided them a leading place in the structure of pharmacy revenues from the sale of AHD and low demand among the population. It should be noted that the ACE inhibitor Preastarium (Servier, Table $8 \mathrm{mg}$ No. 30) and the renin rasillis inhibitor (Novartis Pharma, Table 300 mg No. 28) were among the TOP-5 leaders in terms of sales in UAH for two years. The first of them has the highest cost of packaging among ACE inhibitors, presented in pharmacies (97.70 USD); the second is the drug with the highest cost of packing among the AHD from the range of the pharmacy (350.00 UAH). Therefore, the high profits, that pharmacies receive from the sale of these drugs, is likely related to the active work of medical representatives of pharmaceutical companies. In addition, the inhibitor of renin Rascellus belongs to the new AHD, which were appeared not so long ago in the Ukrainian pharmaceutical market. Other high value packagings also had low consumption among the population.

Acquiring most AHDs by patients in pharmacies was appropriate and necessary for the treatment of hypertension, because $94 \%$ of TN AHDs from the range of the pharmacy were available in the State form of Ukraine (they had an index "V" based on the results of the VENanalysis) in 2017.

They include all the drugs that brought the most profits to pharmacies, as well as those that were in high demand by the population.

\section{Conclusions}

Domestic generic antihypertensive drugs with low cost of packaging were sold most often in drugstores. However, these drugs may differ from the original drugs for clinical efficacy, which can significantly affect the outcome of treatment. In order to provide rational pharmacotherapy for arterial hypertension and given that only a part of the trade names of antihypertensive drugs presented in the pharmaceutical market of Ukraine are available in the pharmacy's range, it is expedient to optimize the range of AHD in this pharmacy based on the results of $\mathrm{ABC}, \mathrm{VEN}$ and frequency analysis.

\section{References}

1. Arterial hypertension: new approaches to treatment // Weekly PHARMACY. 2010. Issue 22 (743).

2. Recommendations of the Ukrainian Association of Cardiologists on the Prevention and Treatment of Arterial Hypertension: A Guide to the National Program for the Prevention and Treatment of Arterial Hypertension. 4th ed., corrected and supplemented. Kyiv, 2008. 55 p.

3. Directory Search Engine "Medicines" of company «Morion» (electronic version, September 2009 and September 2010)

4. Regulations on the State Form of Medicines. URL: http://www.pharma-center.kiev.ua

5. Order of the Ministry of Health of Ukraine No. 1081 dated 06.12.2010 "On Approval of the List of Medicinal Products Permitted for Use in Ukraine, which are Dispensed Without Prescriptions from Pharmacies and their Departments" (regulatory and legal information) // Weekly PHARMACY. 2011. Issue 2 (773).

6. Aliskiren in the treatment of arterial hypertension in patients with obesity // Health of Ukraine. 2011. Issue 8 (261).

7. Methodology for creating drug forms. Order No. 529 of the Ministry of Health of Ukraine of July 22, 2009. URL: http://www.pharma-center.kiev.ua

8. Kirichek L. T. New Approaches to Traditional Antihypertensive Therapy // The Art of Treatment. 2006. Issue 9 (35). URL: http://m-l.com.ua/?aid=933

9. State Form of Medicines (second issue). URL: http://www.pharma-center.kiev.ua/view/formylar/

10. State Form of Medicines / V. T. Chumak (Ed.). Kyiv: MORION, 2009. 1160 p.

11. Clinical and economic analysis / Vorobiev P. A., Avksentyeva M. V., Borisenko O. V. et. al.; P. A. Vorobyov (Ed.). 3rd Ed. Moscow: Nudeamed, 2008. 778 p.

12. Arterial hypertension // Medicinal meridian (popular medicine supplement to the journal "Leccher"). 2008. Issue 1.

Дата надходження рукопису 13.03.2018

Sakhanda Ivanna, assistant, Department of Pharmacy and Industrial Technology of Drugs, Bogomolets National Medical University, Taras Shevchenko blvd., 13, Kyiv, Ukraine, 01601, E-mail: sahanda.ivanna@ ukr.net

Kosyachenko Kostyantyn, Doctor of Pharmaceutical Sciences, Associate Professor, Head of Department, Department of Organization and Economics of Pharmacy, Bogomolets National Medical University. Taras Shevchenko blvd., 13, Kyiv, Ukraine, 01601, E-mail: provisor@i.ua

Nehoda Tetyana, PhD, Associate Professor, Department of Pharmacy and Industrial Technology of Drugs. Bogomolets National Medical University, Taras Shevchenko blvd., 13, Kyiv, Ukraine, 01601

E-mail: t-negoda@meta.ua 